\title{
As Sequelas que o PaSSAdo OPEROU NO FUtURo: A PERDA DA CHANCE DAS VÍTIMAS DO REGIME MILITAR BRASILEIRO E A RESPONSABILIDADE ESTATAL ${ }^{2}$
}

\author{
The after-effects that operated the past in the future: the loss of chance \\ of victims of military regime and brazilian state responsibility
}

\author{
Aline Swarovsky \\ Mestre em Direito pela Universidade de Santa Cruz do Sul - Unisc. \\ Integrante do Grupo de Estudos e Pesquisas "Estado, Administração \\ Pública e Sociedade”. E-mail: aline.swa@gmail.com
}

RECEBIDO EM: 31.08 .12

APROVADO EM: 07.11.12

\section{RESUMO}

O presente estudo se dedica a tratar do tema da responsabilidade civil do Estado em razão das violações perpetradas durante o regime militar brasileiro, especialmente no que diz com a prospecção destes danos no futuro das vítimas. Para isso, será feito um estudo acerca da natureza jurídica dos danos provocados pelo regime militar nas vítimas diretas e indiretas dos atos de tortura, sequestro, morte e desaparecimento, com destaque para a irreversibilidade destes prejuízos. Na sequência, o trabalho se dedicará ao exame responsabilidade civil do Estado, com destaque para o atual tratamento jurisprudencial do tema no que concerne aos atos atentatórios aos direitos humanos praticados no período, bem como a uma análise crítica quanto à capacidade desta teoria em assegurar uma reparação integral dos danos decorrentes destas violações. Por fim, serão demarcados os contornos teóricos e normativos da teoria da perda chance e suas formas de densificação material nos casos sob comento, demonstrando sua adequação ao ordenamento jurídico brasileiro, bem como sua capacidade de

\footnotetext{
${ }^{2}$ Este texto é fruto das pesquisas que estão sendo desenvolvidos no Grupo de Pesquisa sobre Verdade, memória e justiça: análises da experiência das políticas públicas reparatórias do governo do RS envolvendo os atos de sequestro, morte, desaparecimento e tortura de pessoas no regime militar brasileiro (1964/1985), junto ao Programa de Doutorado e Mestrado da Universidade de Santa Cruz do Sul - Unisc, e vinculado ao Diretório de Grupo do CNPQ intitulado Estado, Administração Pública e Sociedade, coordenado pelo Prof. Dr. Rogério Gesta Leal.
} 
proporcionar uma indenização que leve em conta as chances de vida desperdiçadas e os destinos modificados em razão das atrocidades cometidas durante o regime militar, e assim, assinale o comprometimento do Estado com o esclarecimento da verdade, o respeito à memória e a busca pela justiça.

Palavras-chave: Teoria da Perda da chance. Regime militar Brasileiro. RESPONSABILIDADE ESTATAL.

\section{Abstract}

This study is dedicated to address the issue of liability of the state because of violations committed during the military regime in Brazil, especially in those with damage in the future exploration of the victims. This will be done a study on the legal nature of the damage caused by the military regime in direct and indirect victims of torture, kidnapping, disappearance and death, especially the irreversibility of these losses. As a result, the work will be devoted to the examination liability of the state, especially the current jurisprudential treatment of the subject in relation to acts detrimental to human rights committed during the period, as well as a critical analysis regarding the ability of this theory to ensure a full compensation for the damage resulting from these violations. Finally, the contours are marked theoretical and normative theory of loss of chance and its forms of material densification in the case under comment, demonstrating its suitability for the Brazilian legal system, as well as its ability to provide compensation that takes into account the life chances wasted and destinations modified because of the atrocities committed during the military regime, and thus mark the commitment of the State to clarify the truth, respect for the memory and the search for justice.

Keywords: Theory of loss of Chance. Brazilian military Regime. State RESPONSIBILITY.

SuMáRIo: Introdução. 1. Sobre a natureza jurídica dos danos provocados pelo regime militar brasileiro nas vítimas diretas e indiretas dos atos de desaparecimento, morte, sequestro e tortura. 2. A evolução da responsabilidade civil estatal: a consagração da responsabilidade objetiva e sua (in)capacidade para dar conta dos danos provocados pelo regime militar. 3. A perda da chance das vítimas das ações de Estado no regime militar brasileiro e as possibilidades de reparação e indenização: por uma nova teoria da responsabilidade. Conclusão. Referências. 


\section{INTRODUÇÃO}

Neste ensaio pretende-se tratar do tema que envolve a responsabilidade do Estado brasileiro em face das sequelas que o regime militar provocou no futuro de suas vítimas, em especial, no que tange à questão do que se pode chamar de perda da chance nos seus porvires.

Para tanto, o presente estudo se dedica, inicialmente, à análise da natureza jurídica das violações cometidas durante o período do regime militar brasileiro, para, por meio da evolução da teoria da responsabilidade civil, examinar a sua aptidão ou não, para reparar aos danos provocados, e, por fim, lançando mão da teoria da perda da chance, demonstrar, nos seus pormenores, as possibilidades de indenização das chances perdidas das vítimas diretas e indiretas dos atos de desaparecimento, morte, sequestro e tortura.

\section{Sobre a natureza jurídica dos danos provocados pelo regime MILITAR BRASILEIRO NAS VÍTIMAS DIRETAS E INDIRETAS DOS ATOS DE DESAPARECIMENTO, MORTE, SEQUESTRO E TORTURA}

O regime militar brasileiro foi um período em que se operaram diversas agressões aos opositores políticos do regime, constituindo-se estes em danos materiais e, principalmente, imateriais, como os danos físicos, morais, psíquicos e gentílicos.

A respeito deste período obscuro da história brasileira, que vem sendo, paulatinamente, descortinado, ponderam Weuchert e Fávero:

O período historicamente denominado de "ditadura militar" (1964 a 1985) foi marcado pela supressão de direitos constitucionais, censura, perseguição e repressão contra setores da população civil considerados como opositores do regime. Tudo feito mediante uma série de graves violações aos direitos humanos, conforme oficialmente reconhecido através dos artigos $8^{\circ}$ e $9^{\circ}$ do Ato das Disposições Constitucionais Transitórias, da Lei ${ }^{\circ}$ 9.140/95 e da publicação da Presidência da República "Direito à Memória e à Verdade".

A difícil questão que se enfrenta é que estes danos efetivamente ocorreram, mas, em contrapartida, a maior parte das vítimas e dos familiares das vítimas

\footnotetext{
${ }^{3}$ WEUCHERT, Marlon; FÁVERO, Eugênia Augusta Gonzaga. Crimes cometidos no Brasil durante o regime militar por agentes públicos contra a população civil: dever estatal de apurar e responsabilizar. Texto apresentado no $8^{\circ}$ Encontro Nacional da 2a Câmara Criminal do Ministério Público Federal. Disponível em: http://www.2ccr.pgr.mpf.gov.br . Acessado em: 23.08.2012. p. 2.
} 
destas agressões não tiveram acesso à tutela adequada. Grande parte desta situação é fruto da Lei de Anistia (Lei n ${ }^{\circ} 6.683 / 1979$ ), a qual concedeu anistia ${ }^{4}$ ampla, geral e irrestrita a todos os agentes repressores da ditadura militar, bem como aos opositores do regime político, numa espécie de "anistia recíproca".

Consoante artigo $1^{\circ}$ da referida lei, a anistia é concedida a todos que "cometeram crimes políticos ou conexos com estes." Sendo que o parágrafo $1^{\circ}$ do mesmo artigo se encarrega de esclarecer que "consideram-se conexos, para efeito deste artigo, os crimes de qualquer natureza relacionados com crimes políticos ou praticados por motivação política".

Isto significa que a vigência da Lei de Anistia, nos exatos termos em que promulgada, implica na absolvição, dos agentes públicos da repressão pela prática, dentre outras violências, de homicídios, desaparecimentos forçados, abuso de autoridade, lesões corporais, estupro e atentado violento ao pudor.

Justamente em razão das restrições impostas pela Lei de Anistia e, bem assim, pelo próprio ordenamento jurídico brasileiro, que, por muito tempo, a discussão sobre o assunto permaneceu inerte, razão pela qual não há, atualmente, uma classificação, ou mesmo uma mobilização, por parte da doutrina e/ou jurisprudência, no sentido de identificar a natureza jurídica das violações e agressões que ocorreram no período da ditadura militar brasileira.

Some-se isso ao fato de ser o Brasil o único país da América Latina que não reviu sua Lei de Anistia, evidenciando que há um descompasso entre a evolução do tema nos países vizinhos e o engessamento do mesmo no caso brasileiro.

Aliás, esta tendência foi corroborada, recentemente, pelo julgamento da Arguição de Descumprimento de Preceito Fundamental (ADPF) $n^{\circ} 153$, em que a Suprema Corte brasileira rejeitou o pedido da Ordem dos Advogados do Brasil (OAB) de declaração de inconstitucionalidade da interpretação dada ao $\S 1^{\circ}$ do artigo $1^{\circ}$ da Lei $n^{\circ} 6.683 / 79$, que estende a anistia aos crimes comuns praticados pelos agentes da repressão.

\footnotetext{
${ }^{4}$ Lei n ${ }^{\circ} 6.683 / 1979$, Art. $1^{\circ}$. É concedida anistia a todos quantos, no período compreendido entre 02 de setembro de 1961 e 15 de agosto de 1979, cometeram crimes políticos ou conexo com estes, crimes eleitorais, aos que tiveram seus direitos políticos suspensos e aos servidores da Administração Direta e Indireta, de fundações vinculadas ao poder público, aos Servidores dos Poderes Legislativo e Judiciário, aos Militares e aos dirigentes e representantes sindicais, punidos com fundamento em Atos Institucionais e Complementares (vetado). $\$ 1^{\circ}$ - Consideram-se conexos, para efeito deste artigo, os crimes de qualquer natureza relacionados com crimes políticos ou praticados por motivação política. A esse respeito, impende destacar que "Crime político puro é crime de opinião, cujo autor, ou sujeito ativo, discorda intelectualmente das diretrizes políticas de um governo, como fizeram muitos militantes de esquerda, no Brasil, após o golpe militar de 1964, refugiando-se, a seguir, no Chile, na Argélia, na Europa, principalmente em países do Leste europeu. O crime político puro não é crime de sangue e nem envolve violência física ou psíquica." Grifos aditados (QUEIROZ, Carlos Alberto Marchi de. Crime político e crime comum. Disponível em: www.adesp.org.br. Acessado em 05.05.2012).
} 
A partir deste quadro, verifica-se, atualmente, que existem muitos entraves à conceituação da natureza jurídica dos danos causados pelos agentes da repressão. Como bem asseverado pelo Procurador Geral da República, na ADPF 153, a anistia destina-se ao crime, "retirando-lhe o caráter delituoso e, por consequência, excluindo a punição dos que o cometeram"s.

Sendo assim, por óbvio que a exclusão deste caráter delituoso implicou, por muito tempo, na anulação de qualquer tentativa de responsabilização por parte do Estado, desmotivando muitas vítimas e familiares de vítimas a buscar alguma espécie de reparação pelos danos sofridos.

Foi assim que, para ter acesso a uma tutela mais ampla e efetiva, foi proposta, para a análise da Corte Interamericana de Direitos Humanos, no dia 7 de agosto de 1995, pelos familiares das pessoas relacionadas com o movimento da Guerrilha do Araguaia (1972 a 1975), uma demanda contra a República Federativa do Brasil, em face de: a) sua responsabilidade pela detenção ilegal e arbitrária, tortura e desaparecimento forçado de pelo menos 70 pessoas e pela execução extrajudicial de Maria Lucia Petit da Silva, e; b) da ausência de qualquer investigação desses atos, o que está relacionado à edição da Lei $n^{\circ} 6.683 / 79$, denominada Lei de Anistia e com a restrição do acesso aos documentos e informações atinentes a esta operação estatal.

Como após a emissão do relatório de mérito do Caso, em que foram realizadas recomendações ao Brasil, a Comissão Interamericana entendeu que o país não as havia cumprido de forma satisfatória, determinou o encaminhamento do Caso à Corte para julgamento.

$\mathrm{Na}$ decisão proferida no dia 24 de novembro de 2010, o Brasil foi considerado responsável pela violação dos seguintes direitos assegurados pela Convenção Interamericana: à personalidade jurídica (artigo 3), à vida (artigo 4), à integridade pessoal (artigo 5) em razão do sofrimento gerado pela impunidade dos responsáveis, assim como pela falta de acesso à justiça, à verdade e à informação, pela violação da direito à liberdade pessoal (artigo 7), dos direitos às garantias judiciais (artigo 8.1) e à proteção judicial (artigo 25) em virtude da aplicação da lei de anistia à investigação sobre os fatos, e, por fim, pela violação do direito à liberdade de pensamento e expressão (artigo 13), em razão da falta de acesso à informação sobre o ocorrido ${ }^{6}$.

\footnotetext{
${ }^{5}$ BRASIL. Supremo Tribunal Federal. ADPF 153, Rel. Ministro Eros Grau. Tribunal Pleno, julgado em 29/04/2010, DJ 06/08/10. Disponível em: http://www.stj.jus.br. Acessado em 23.08.2012. p. 7.

6 CORTE INTERAMERICANA DE DIREITOS HUMANOS. Demanda da Comissão Interamericana de Direitos Humanos perante a Corte Interamericana de Direitos Humanos contra a República Federativa do Brasil: Caso 11.552 - Julia Gomes Lund e Outros (Guerrilha do Araguaia). In: Revista Anistia Política e Justiça de Transição, Brasília: Ministério da Justiça, n. 2, p. 473, jul./dez. 2009.
} 
Assim, a Corte Interamericana entendeu que a Lei de Anistia serviu com um subterfúgio para obstacularizar a investigação e o julgamento de crimes contra a humanidade, uma vez que a atual Constituição não reservou espaço para a condenação penal dos agentes da repressão. Ou seja, o Estado brasileiro é responsável, tanto pelas violações, como pelo seu desinteresse em buscar, de alguma forma, reparar as violências perpetradas.

Em que pese a atual controvérsia acerca da Lei de Anistia, consistente na existência de uma condenação da Corte Internacional exigindo a revisão da lei e a Corte Suprema do Estado Brasileiro, negando qualquer possibilidade de sua revisão, o fato é que nenhuma das instâncias nega a existência destes crimes, que, por óbvio acarretaram danos, tanto materiais como imateriais.

Com relação aos danos imateriais, a reparação diz principalmente com as práticas violadoras de liberdade, com os danos físicos, consubstanciados em atos de perseguição, sequestro, tortura, execução e desaparecimento, ou seja, formas de tratamento cruel e desumano, lesivas da integridade psíquica e moral do ser humano; na assunção de uma condição indigna e incompatível com as garantias coferidas pelos Direitos Humanos, objeto de proteção na esfera internacional. Eles dizem respeito, ainda, aos sentimentos de dor, sofrimento, angústia e irresignação que atingiram os familiares das vítimas.

Acerca da natureza dos danos sofridos pelas vítimas da Guerrilha do Araguaia, que, por similitude, pode-se aplicar aos demais atingidos, direta ou indiretamente, pelo regime militar, a Corte reconheceu dois processos de causalidade:

O primeiro descreve as implicações automáticas que surgem da violação de direitos e liberdades protegidos: a determinação da responsabilidade estatal e o dever consequente de cessar de imediato a conduta errônea. Um segundo processo está relacionado às consequências das ações contrárias à Convenção. Quando o dano não for reparado pela mera cessação da conduta contrária à Convenção, tais consequências também devem ser reparadas ${ }^{7}$.

Portanto, no que diz respeito à natureza jurídica desses danos, por serem crimes atentatórios aos Direitos Humanos, faz-se necessária a responsabilização do Estado, aliada à cessação da conduta ilícita. Todavia, quando, pela simples abstenção da prática desta conduta, o dano não for reparado, as consequências danosas da irreversibilidade desta situação também deverão ser objeto de reparação.

\footnotetext{
${ }^{7}$ Corte Interamericana de Direitos Humanos. Demanda da Comissão Interamericana de Direitos Humanos perante a Corte Interamericana de Direitos Humanos contra a República Federativa do Brasil: Caso 11.552 - Julia Gomes Lund e Outros (Guerrilha do Araguaia). In: Revista Anistia Política e Justiça de Transição, Brasília: Ministério da Justiça, n. 2, p. 466, jul./dez. 2009.
} 
Nesse sentido, a Corte declarou que as violações perpetradas são diversas e englobam graves danos físicos e morais. Sustenta, ainda, que os familiares vêm enfrentando dois obstáculos insuperáveis até o presente momento, consubstanciados na impunidade e no sigilo, os quais foram construídos e fortalecidos ao longo do tempo, mediante ações estatais direcionadas para este fim $^{8}$.

Aliado a isso, a Corte possui jurisprudência pacífica no sentido de considerar presumida a existência de dano imaterial por parte das famílias das vítimas:

Segundo o estabelecido pelo Tribunal, o fato de que as autoridades não hajam sido capazes de descobrir a verdade sobre violações de direitos humanos de tamanha gravidade pode gerar intensos sofrimentos e angústia para os familiares, assim como sensações de insegurança, frustração e impotência, o que efetivamente ocorreu no presente caso e, ademais, foi agravado pela falta de acesso à informação sobre os acontecimentos ${ }^{9}$.

A partir disso, reconhece, expressamente, a existência do dano moral como consequência intrínseca à natureza das violações praticadas, que atingem a mais alta classe de direitos, os ditos humanos, que são inerentes à condição humana. Como bem explicitado pelo jurista chileno Gallo, os direitos humanos, "diferentemente do que ocorre com outros direitos - que são adquiridos no decorrer da existência, mediante outorga do Estado, ou ajustes interpessoais, ou prática de atos autorizados por lei, são eles inatos ${ }^{10}$ ".

Igualmente, no caso do ordenamento jurídico brasileiro,

A possibilidade de se indenizar os danos extrapatrimoniais pacificouse na doutrina e na jurisprudência, pois se verificou que, em verdade, ao quantificar-se o montante da indenização de tais danos, não se está a reparar o prejuízo, mas a compensá-lo, de forma a amenizar o abalo sofrido ${ }^{11}$.

8 CORTE INTERAMERICANA DE DIREITOS HUMANOS. Demanda da Comissão Interamericana de Direitos Humanos perante a Corte Interamericana de Direitos Humanos contra a República Federativa do Brasil: Caso 11.552 - Julia Gomes Lund e Outros (Guerrilha do Araguaia). In: Revista Anistia Política e Justiça de Transição, Brasília: Ministério da Justiça, n. 2, p. 466, jul./dez. 2009.

${ }^{9}$ Corte Interamericana de Direitos Humanos. Demanda da Comissão Interamericana de Direitos Humanos perante a Corte Interamericana de Direitos Humanos contra a República Federativa do Brasil: Caso 11.552 - Julia Gomes Lund e Outros (Guerrilha do Araguaia). In: Revista Anistia Política e Justiça de Transição, Brasília: Ministério da Justiça, n. 2, pp. 467-468, jul./dez. 2009.

${ }^{10}$ GALLO, Hübner apud OLIVEIRA, Almir de. Curso de Direitos Humanos. Rio de Janeiro: Forense, 2000, pp. 97-98.

${ }^{11}$ ROCHA. Vivian de Almeida Sieben. A responsabilidade civil pela perda da chance no direito 
Assim, embora haja dificuldade quanto à caracterização destes danos, a partir da decisão proferida pela Corte Interamericana de Direitos Humanos, abriram-se reias possibilidades de reparação, pois, pela primeira vez, reconheceu-se a imprescindibilidade do Estado Brasileiro em tomar medidas que, além de meras indenizações, representem o seu comprometimento no trato das questões envolvendo violações de Direitos Humanos.

Da mesma forma, conquanto ainda se verifique forte resistência pela Corte brasileira, no reconhecimento desses crimes, o fato é que os Tribunais Internacionais trabalham com a transformação do paradigma vigente no país, ou seja, a passagem de uma cultura de impunidade para uma cultura de responsabilidade.

Resta agora perquirir se a atual teoria da responsabilidade estatal, consagrada no art. $37, \S 6^{\circ}$ da Constituição configura-se como suficiente para corresponder às expectativas das vítimas das violações de direitos perpetradas durante o período ditatorial em comento.

\section{A EVOluÇão da RESPONSABILIDAde CIVIL ESTATAl: A CONSAGRAÇÃo da RESPONSABILIDADE OBJETIVA E SUA (IN) CAPACIDADE PARA DAR CONTA DOS DANOS PROVOCADOS PELO REGIME MILITAR}

A responsabilidade civil é um tema que vem apresentando gradual evolução ao longo do tempo. Constitui-se, de uma forma geral, em uma obrigação que surge toda vez que alguém causa um dano a outrem - o qual pode atingir sua esfera moral, patrimonial ou ambas - e encerra-se com a respectiva indenização.

Com base nesta noção, pode-se definir a responsabilidade civil como a imposição de condutas que "obriguem alguém a reparar dano moral ou patrimonial causado a terceiros em razão de ato próprio imputado, de pessoa por quem ele responde, ou de fato de coisa ou animal sob sua guarda ou, ainda, de simples imposição legal"12.

No âmbito da Administração, entende-se como aquela que, "[...] impõe à Fazenda Pública a obrigação de compor o dano causado a terceiros por agentes públicos, no desempenho de suas atribuições ou a pretexto de exercê-las ${ }^{13}$ ".

Porém, nem sempre foi assim. Por um longo período vigeu o paradigma

brasileiro. In: Direito e Justiça, Porto Alegre, vol. 36, n. 1, p. 48, jan./jun. 2010.

${ }_{12}^{12}$ DINIZ, Maria Helena. Curso de direito civil brasileir. vol. 7. São Paulo: Saraiva, 2007. p. 34.

${ }^{13}$ MEIRELLES, Hely Lopes. Direito administrativo brasileiro. 25. ed. São Paulo: Malheiros, 2000. p. 595. 
da inimputabilidade dos governantes. Seu marco inicial se deu com a irresponsabilidade presente no Estado absolutista, em que perdurava a máxima "the king can do no wrong", que poderia ser traduzida como "o rei não pode errar/ser responsabilizado". Esta teoria somente passou a ser revista após a Primeira Guerra Mundial, consoante demarcado por Lewandowski:

A tese da inimputabilidade dos governantes somente começou a modificar-se depois da Primeira Guerra Mundial, em virtude da destruição sem precedentes causada pelo emprego das novas armas de extermínio em massa e diante das indizíveis atrocidades praticadas pelas potências beligerantes nos campos de batalha e fora deles, que levaram à morte mais de 15 milhões de pessoas. Isso fora o massacre de cerca de um milhão de armênios, pelos turcos, em 1915.

Embora até essa época jamais um governante, chefe militar ou mesmo simples soldado tenha sido responsabilizado por crimes cometidos em ações bélicas, as potências vencedoras, capitaneadas por Lloyd George e David Clemenceau, respectivamente chefes de governo da Grã-Bretanha e da França, manifestaram a intenção de punir aqueles que praticaram atos ofensivos às leis da humanidade e às normas de conduta civilizada durante a guerra. O Tratado de Paz de Versalhes, de 1919, até chegou a incluir um dispositivo nesse sentido, pois os aliados pretendiam levar o imperador Guilherme II da Alemanha a julgamento. Mas a punição dos vencidos, como se sabe, resumiu-se a uma vultosa indenização, jamais paga integralmente ${ }^{14}$.

Nos anos que se seguiram à celebração do tratado de paz, alguns esforços foram empreendidos com vistas à instituição de uma corte criminal internacional, sendo, todavia, desencorajados pela resistência da comunidade diplomática, ainda muito afeta à noção de irresponsabilidade dos agentes estatais. $\mathrm{O}$ apego a esta tese ultrapassada custou um preço muito alto à humanidade: a eclosão da Segunda Guerra Mundial, muito mais violenta do que a primeira, que dizimou com a vida de 55 milhões de pessoas ${ }^{15}$.

Destarte, a inimputabilidade dos governantes e, assim, dos Estados que permitiram a prática destas barbáries, somente tomou contornos mais efetivos

\footnotetext{
${ }^{14}$ LEWANDOWSKI, Enrique Ricardo. O Tribunal Penal Internacional: de uma cultura de impunidade para uma cultura de responsabilidade. In: Estudos Avançados. São Paulo, vol. 16, n. 45, p. 189, maio/ago 2002. Grifos aditados.

${ }^{15}$ LEWANDOWSKI, Enrique Ricardo. O Tribunal Penal Internacional: de uma cultura de impunidade para uma cultura de responsabilidade. In: Estudos Avançados, São Paulo, vol. 16, n. 45, p. 189, maio/ago 2002.
} 
após duas grandes guerras mundiais, que ocasionaram o massacre de milhões de pessoas, chamando a atenção da comunidade internacional para a gravidade e as consequências das violações cometidas.

Portanto, esta modalidade de responsabilização sofreu um processo de lenta evolução no tempo. No Brasil, a consagração da responsabilidade objetiva do Estado sobreveio com a Constituição Federal de 1946, a partir da eleição da teoria do risco administrativo. Esta sistemática foi reproduzida na Constituição seguinte, do ano 1988, na qual ficou consignada, no art. 37, § $6^{\circ}$, a expansão dessa responsabilidade às pessoas jurídicas de direito público e às de direito privado prestadoras de serviços públicos que, nessa qualidade, causem danos a terceiros ${ }^{16}$.

Diniz, utilizando-se dos ensinamentos de Bandeira de Mello, indica que a responsabilidade civil aquiliana do Estado é uma implicação do princípio da legalidade, sendo que, no caso de comportamentos ilícitos comissivos, será igualmente do princípio da isonomia ou da igualdade de todos perante a lei e, na hipótese de atos lícitos e na de danos relacionados à circunstância criada pelo Poder Público - ainda que o autor da lesão não seja o Estado - do princípio da igualdade, porquanto o fundamento desta forma de responsabilidade é garantir a distribuição igualitária dos ônus do evento danoso, impedindo que uns suportem os prejuízos de atividades que são desenvolvidas para o benefício da coletividade ${ }^{17}$ ”

Faz-se necessário, também, analisar os dispositivos legais atinentes à responsabilidade civil do Estado. Na Constituição da República, está prevista no $\S 6^{\circ}$ do art. 37 :

As pessoas jurídicas de direito público e as de direito privado prestadoras de serviços públicos responderão pelos danos que seus agentes, nessa qualidade, causarem a terceiros, assegurado o direito de regresso contra o responsável nos casos de dolo e culpa.

Da mesma forma, O Código Civil também dispõe sobre a responsabilidade civil do Estado no art. 43:

As pessoas jurídicas de direito público interno são civilmente responsáveis por atos dos seus agentes que nessa qualidade causem danos a terceiros, ressalvado o direito regressivo contra os causadores do dano, se houver, por parte destes, culpa ou dolo.

\footnotetext{
${ }^{16}$ RODYCZ, Wilson Carlos. A responsabilidade civil das empresas privadas por danos causados na prestação de serviços públicos delegados. In: Revista de Direito do Consumidor, São Paulo, n. 45, p. 192, jan./março 2003.

${ }^{17}$ DINIZ, Maria Helena. Curso de direito civil brasileiro. vol. 7. São Paulo: Saraiva, 2007. p. 613.
} 
A partir dos dispositivos supra, iniciando-se pela Constituição da República, tem-se as seguinte premissas: a responsabilidade estatal é objetiva, prescindindo da análise da culpa para a ocorrência do dano, bastando, para tanto, a comprovação da efetividade da lesão sofrida pela vítima, seja de natureza material ou moral, e a existência do nexo causal, isto é, da relação de causa e efeito entre a conduta praticada pelo Estado e o dano acarretado à vítima.

Todavia, com relação às violações cometidas durante o regime militar, a inovação ficou por conta da Lei $n^{\circ} 9.140 / 95$, porquanto, ao mesmo tempo em que reconheceu (artigo $\left.1^{\circ}\right)^{18}$, como mortas, para todos os efeitos legais, as pessoas desaparecidas durante o período de 2 de setembro de 1961 a 5 de outubro de 1988, também definiu (artigo 11) ${ }^{19}$, um quantum indenizatório para as vítimas atingidas direta e indiretamente por esses atos.

Segundo a Comissão Especial sobre Mortos e Desaparecidos Políticos, "a lei 9.140/95 marcou o reconhecimento, pelo Estado brasileiro, de sua responsabilidade no assassinato de opositores políticos no período abrangido ${ }^{20 "}$.

Com base nestes pressupostos, o Superior Tribunal de Justiça tem reconhecido a responsabilidade civil do Estado, destacando a imprescritibilidade das ações indenizatórias por danos morais e materiais, decorrentes dos crimes de lesa humanidade, cometidos pelos agentes da repressão durante o regime militar:

Administrativo e processual civil. Agravo regimental no agravo de instrumento. Responsabilidade civil do Estado. Ação de reparação de danos. Perseguição política e tortura durante o regime militar. Imprescritibilidade de pretensão indenizatória decorrente de violação de direitos humanos fundamentais durante o período de exceção. Inaplicabilidade do art. $1 .^{\circ}$ do Decreto n. ${ }^{\circ}$ 20.910/32. Violação do art. 535 do CPC que não se verifica. Configuração da condição de anistiado e redução da verba indenizatória. Acórdão recorrido que dirimiu a

\footnotetext{
${ }^{18}$ Art. $1^{\circ}$. São reconhecidos como mortas, para todos os efeitos legais, as pessoas que tenham participado, ou tenham sido acusadas de participação, em atividades políticas, no período de 2 de setembro de 1961 a 5 de outubro de 1988, e que, por este motivo, tenham sido detidas por agentes públicos, achando-se, deste então, desaparecidas, sem que delas haja notícias.

${ }^{19}$ Art. 11. A indenização, a título reparatório, consistirá no pagamento de valor único igual a $\mathrm{R} \$ 3.000,00$ (três mil reais) multiplicado pelo número de anos correspondentes à expectativa de sobrevivência do desaparecido, levando-se em consideração a idade à época do desaparecimento e os critérios e valores traduzidos na tabela constante do Anexo II desta Lei. $\$ 1^{\circ}$ Em nenhuma hipótese o valor da indenização será inferior a $\mathrm{R} \$ 100.000,00$ (cem mil reais). $\$ 2^{\circ} \mathrm{A}$ indenização será concedida mediante decreto do Presidente da República, após parecer favorável da Comissão Especial criada por esta Lei.

${ }^{20}$ BRASIL. Direito à verdade e à memória: Comissão Especial sobre Mortos e Desaparecidos Políticos. Brasília: Secretaria Especial dos Direitos Humanos, 2007. p. 17.
} 
controvérsia com base no acervo probatório dos autos. Reforma do julgado. Impossibilidade. Incidência da súmula 7/STJ. 1. Constatado que a Corte de para dirimir a controvérsia, é de se afastar a alegada violação do art. 535 do CPC. 2. A jurisprudência do Superior Tribunal de Justiça firmou o entendimento de que "As ações indenizatórias por danos morais e materiais decorrentes de atos de tortura ocorridos durante o Regime Militar de exceção são imprescritíveis. Inaplicabilidade do prazo prescricional do art. $1^{\circ}$ do Decreto 20.910/1932." (EREsp n ${ }^{\circ}$ 816.209/RJ, Relatora Ministra Eliana Calmon, Primeira Seção, in DJe 10/11/2009). Isso, porque as referidas ações referem-se a período em que a ordem jurídica foi desconsiderada, com legislação de exceção, havendo, sem dúvida, incontáveis abusos e violações dos direitos fundamentais, mormente do direito à dignidade da pessoa humana. Precedentes: REsp 959.904/PR, Rel. Ministro Luiz Fux, Primeira Turma, DJe 29/9/2009; AgRg no Ag 970.753/MG, Rel. Ministra Denise Arruda, Primeira Turma, DJe 12/11/2008; REsp 449.000/PE, Rel. Ministro Franciulli Netto, Segunda Turma, DJ 30/6/2003. 3. O Tribunal a quo, analisando os fatos da causa, concluiu que houve inequívoca "perseguição política", estando, portanto, preenchidos os requisitos para se obter a reparação de danos prevista na lei, e inverter essa conclusão, bem como discutir a pretendida redução da verba indenizatória, implica incursão no universo fáctico-probatório dos autos, o que é vedado em razão do óbice contido no enunciado $\mathrm{n}^{\circ} 7$ da Súmula do STJ. 4. Agravo regimental não provido. ${ }^{21}$.

Administrativo e processual civil. Agravo regimental no recurso especial. Responsabilidade civil do Estado. Ação de reparação de danos. Perseguição política e tortura durante o regime militar. Imprescritibilidade de pretensão indenizatória decorrente de violação de direitos humanos fundamentais durante o período de exceção. Inaplicabilidade do art. 1. ${ }^{\circ}$ do Decreto n. ${ }^{\circ}$ 20.910/32. 1. O STJ pacificou entendimento no sentido de que são imprescritíveis as ações de reparação de danos ajuizadas em decorrência de perseguição, tortura e prisão, por motivos políticos, durante o Regime Militar, afastando-se, por conseguinte, a prescrição quinquenal prevista no art. $1^{\circ}$ do Decreto 20.910/32. Isso, porque as referidas ações referem-se a período em que a ordem jurídica foi desconsiderada, com legislação de exceção, havendo, sem dúvida,

\footnotetext{
${ }^{21}$ BRASIL. Superior Tribunal de Justiça. AgRg noAg. 1.391.062/RS. Relator Benedito Gonçalves, Primeira Turma, julgado em 09/08/2012, DJ 16/08/2012. Disponível em http://www.stj.jus.br. Acessado em 23.08.2012. Grifos aditados
} 
incontáveis abusos e violações dos direitos fundamentais, mormente do direito à dignidade da pessoa humana. Precedentes: REsp 959.904/ PR, Rel. Ministro Luiz Fux, Primeira Turma, julgado em 23/04/2009, DJe 29/09/2009; AgRg no Ag 970.753/MG, Rel. Ministra Denise Arruda, Primeira Turma, julgado em 21/10/2008, DJe 12/11/2008; REsp 449.000/PE, Rel. Ministro Franciulli Netto, Segunda Tturma, julgado em 05/06/2003, DJ 30/06/2003 p. 195.2. Agravo regimental não provido ${ }^{22}$.

Embora os arestos colacionados reconheçam a responsabilidade estatal pelos atos atentatórios aos direitos humanos, significando uma "evolução da jurisprudência" ${ }^{23}$, não estão de acordo com o princípio da reparação integral dos danos, sendo que, apenas com o reconhecimento da responsabilidade civil estatal consagrada no $\S 6^{\circ}$ do art. 37 da Carta Magna, não se está concedendo às vítimas e aos seus familiares uma indenização que leve em consideração todas as perdas ocasionadas por estas violações.

Destaque-se, ademais, que, apesar de a edição da Lei nº 9.140/95 ter representado uma importante conquista no campo das reparações, acabou por estabelecer, artificialmente e sem a devida atenção às peculiaridades de cada caso, o valor da dor, do sofrimento pela tortura, morte e desaparecimento. Ainda, teve o condão de apagar a história e os outros direitos não abrangidos por esta lei, que igualmente foram violados.

Esta visão superficial, limitada e arbitrária acerca das possibilidades de indenização, instituída pela Lei $n^{\circ}$ 9.140/95, se confirma na jurisprudência, conforme demonstram os arestos do STJ acima colacionados. Assim, o atual quadro normativo brasileiro demonstra que a teoria da responsabilidade civil objetiva não é suficientemente adequada para indenizar todas as dimensões de direitos afetadas pelas agressões perpetradas durante o regime militar.

A questão envolvendo estes danos é algo que transcende a noção clássica da responsabilidade civil. E isto porque não ocorreram apenas atos de tortura, desaparecimento forçado, ou execução. Diversas chances de vida foram desperdiçadas. Estas chances, que propagaram seus efeitos no futuro, não estão sendo objeto de análise destas decisões, razão pela qual se faz necessário lançar mão de uma teoria que se ocupe, em seus pormenores, de abranger as demais consequências danosas destes atos.

\footnotetext{
${ }^{22}$ BRASIL. Superior Tribunal de Justiça. AgRg no REsp 1251529/PR. Relator Benedito Gonçalves, Primeira Turma, julgado em 28/06/2011, DJ 01/07/2011. Disponível em http://www.stj.jus.br. Acessado em 23.08. 2012. Grifos aditados.

${ }^{23}$ Expressão referida pela Ministra Relatora Eliana Calmon no julgamento do (EREsp 816209/ RJ). BRASIL. Superior Tribunal de Justiça. EREsp 816209/RJ. Relatora Ministra Eliana Calmon, Primeira Seção, julgado em 28/10/2009, DJ 10/11/2009. Disponível em http://www.stj.jus.br. Acessado em 23.08. 2012.
} 


\section{A perda da chance das vítimas das aÇões de Estado no Regime MILITAR BRASILEIRO E AS POSSIBILIDADES DE REPARAÇÃO E INDENIZAÇÃO: POR UMA NOVA TEORIA DA RESPONSABILIDADE}

As pretensões indenizatórias mais amplas em face das violações cometidas pelos agentes da ditadura militar podem obter seu fundamento a partir da teoria da perda da chance, que, concedendo novo enfoque à teoria da responsabilidade civil, possibilita a análise das variadas dimensões de direitos afetadas.

Esta tese ganha força no contexto das mudanças instituídas pela Comissão da Verdade e da Justiça, pela condenação do Estado brasileiro perante a Corte Interamericana de Direitos Humanos (Caso Guerrilha do Araguaia) e do reconhecimento, por parte do Estado brasileiro (em especial, pela promulgação da Lei $\mathrm{n}^{\circ}$ 9.140/95), das atrocidades perpetradas durante o regime militar.

A teoria da perda da chance (perte d'une chance) surgiu inicialmente na França, como evolução da doutrina e da jurisprudência. Tal conceituação foi utilizada pela primeira vez em 1965, em decisão proferida pela Corte de Cassação Francesa, na análise de um recurso relativo à responsabilidade de um médico que teria realizado diagnóstico equivocado, importando na diminuição das chances de cura da vítima ${ }^{24}$.

Como claramente sintetizado por Savi:

Em razão dos estudos desenvolvidos naquele país, ao invés de se admitir a chance pela vantagem esperada, passou-se a defender a existência de um dano diverso do resultado fina, qual seja, o da perda da chance. Teve início, então, o desenvolvimento de uma teoria específica para estes casos, que defendia a concessão de indenização pela perda da possibilidade de conseguir uma vantagem e não pela perda da própria vantagem perdida.

O termo chance, utilizado pelos franceses significa, em sentido jurídico, a probabilidade de obter um lucro ou evitar uma perda. No vernáculo, a melhor tradução para o termo chance seria, em nosso sentir, oportunidade ${ }^{25}$.

No Brasil, a perda da chance apareceu, de forma inédita, no ano de 2000, por conta do julgamento do Recurso Especial $788459 / \mathrm{BA}^{26}$, no qual o participante

\footnotetext{
${ }^{24}$ GONDIM, Glenda Gonçalves. Responsabilidade civil: teoria da perda de uma chance. In: Revista dos Tribunais, São Paulo, vol. 840, p. 22, out. 2005.

${ }^{25}$ SAVI, Sérgio. Responsabilidade civil por Perda de uma chance. São Paulo: Atlas, 2006. p. 3.

${ }^{26}$ BRASIL. Superior Tribunal de Justiça. REsp 788459/BA. Relator Fernando Gonçalves, Quarta
} 
de um jogo televisivo de perguntas e respostas ("Show do Milhão") pleiteou uma indenização em virtude de pergunta formulada sem resposta, razão que lhe impossibilitou de responder à pergunta que valia um milhão de reais e, assim, de receber o prêmio máximo do programa. Diante disso, solicitava o pagamento do valor equivalente ao prêmio máximo não recebido, correspondente a $\mathrm{R} \$$ 500.000,00 (quinhentos mil reais).

O tribunal de origem acolheu os pedidos formulados pelo participante. Contudo, o acórdão foi reformado pelo Superior Tribunal de Justiça, que reduziu o valor da indenização para $\mathrm{R} \$ 125.000,00$ (cento e vinte e cinco mil reais), correspondente a $25 \%$ do valor requerido, por representar a probabilidade matemática de acerto da resposta de uma pergunta com quatro alternativas.

Fernando Gonçalves, Ministro relator do acórdão, esclarece:

Destarte, não há como concluir, mesmo na esfera da probabilidade, que o normal andamento dos fatos conduziria ao acerto da questão. Falta, assim, pressuposto essencial à condenação da recorrente no pagamento da integralidade do valor que ganharia a recorrida caso obtivesse êxito na pergunta final, qual seja, a certeza - ou a probabilidade objetiva - do acréscimo patrimonial apto a qualificar o lucro cessante ${ }^{27}$.

Observe-se, a partir deste julgado, a indicação dos pressupostos da responsabilidade civil por perda da chance. O primeiro deles é que as chances de se obter uma determinada vantagem ou evitar um prejuízo devem ser sérias e reais, ou seja, não se deve tratar de uma mera possibilidade ou expectativa, pois meras possibilidades ou expectativas não são objeto de indenização por parte do Direito.

Igualmente, o valor da indenização jamais poderá corresponder à vantagem que seria obtida pela vítima caso não tivesse sofrido o dano. "Se assim fosse, estar-se-ia diante de um caso clássico de responsabilidade civil, porquanto o nexo de causalidade entre a conduta e o dano final estaria comprovado ${ }^{28}$ ".

Relacionados estes requisitos, cabe ressaltar que, embora não esteja positivada no ordenamento jurídico brasileiro, a tese da perda da chance encontra fundamento em uma interpretação sistemática dos artigos de lei que versam sobre a obrigação de indenizar, bem como, nos princípios e garantias salvaguardados pela Constituição Federal de 1988.

Turma, julgado em 08/11/2005, DJ 13/03/2006. Disponível em http://www.stj.jus.br. Acessado em 23.08. 2012.

${ }^{27}$ BRASIL. Superior Tribunal de Justiça. REsp 788459/BA. Relator Fernando Gonçalves, Quarta Turma, julgado em 08/11/2005, DJ 13/03/2006. Disponível em http://www.stj.jus.br. Acessado em 23.08.2012. p. 9.

${ }^{28}$ ROCHA. Vivian de Almeida Sieben. A responsabilidade civil pela perda da chance no direito brasileiro. In: Direito e Justiça, Porto Alegre, vol. 36, n. 1, p. 50, jan./jun. 2010. 
Em consonância com este entendimento, Savi informa que há três principais motivos pelos quais a indenização das chances perdidas é admitida no Brasil: a) o primeiro deles é em razão da cláusula geral da responsabilidade civil (artigos 186 e 927, do Código Civil) ${ }^{29}$, que figura como uma cláusula aberta, isto é, trata-se da utilização do conceito amplo de dano, o qual não estabelece um rol dos bens juridicamente protegidos; b) o segundo motivo refere-se ao princípio da reparação integral dos danos, que tem a grande virtude de garantir o direito da vítima ao ressarcimento da totalidade dos danos sofridos, colocando-a na mesma situação que estaria caso os danos não tivessem ocorrido, e, por fim, em função da; c) evolução da responsabilidade civil, que direcionou o seu foco de atenção, da repressão do ato ilícito, para a proteção da vítima do dano injusto ${ }^{30}$.

Destaque-se, portanto, a plena adequação da reparação das chances perdidas com os pressupostos da responsabilização veiculados pelo Código Civil Brasileiro, bem assim, com a nova sistemática inaugurada pela Constituição de 1988, que concentra seus esforços na proteção da pessoa humana, em todas as suas dimensões.

Deste modo, superada a questão da admissibilidade da responsabilização pela perda da chance, a questão que surge é, como se medir as perdas das chances em termos de indenizações, diante do fato de que a perda de uma oportunidade tem um grau de indeterminação muito amplo, especialmente, no caso das atrocidades perpetradas contra as vítimas do regime de exceção.

Adicionalmente, é uma tarefa que exige demarcar algo sobre o qual nunca se teve um parâmetro, uma métrica, o que demonstra a dificuldade quanto à definição do tamanho desta perda, do fenômeno da ausência de existência. Por outro lado, não se pode ignorar que esta perda é amparada pelo direito, em especial, diante do atual paradigma solidarista imputado à responsabilidade civil e do conceito amplo de dano veiculado pelo artigo 927 do atual Código Civil Brasileiro.

Observe-se, por exemplo, o caso dos sucessores das vítimas das violações perpetradas pelo Estado brasileiro. Filhos que tiveram seus pais desaparecidos ou executados e que, em razão disso, tiveram toda sua vida desestruturada, interromperam os estudos em busca de sustento, perderam a chance de usufruir de melhores condições intelectuais e sociais e, acima de tudo, tiveram a oportunidade de convivência com seus pais injustamente expropriada pelas mãos do Estado.

Nas palavras de Rocha, a situação acima descrita,

\footnotetext{
${ }^{29}$ Art. 186. Aquele que, por ação ou omissão voluntária, negligência ou imprudência, violar direito e causar dano a outrem, ainda que exclusivamente moral, comete ato ilícito. Art. 927. Aquele que, por ato ilícito (arts. 186 e 187), causar dano a outrem, fica obrigado a repará-lo.

${ }^{30}$ SAVI, Sérgio. Responsabilidade civil por Perda de uma chance. São Paulo: Atlas, 2006. pp. 83-95.
} 
[...] não obstante desprovida de certeza acerca do nexo de causalidade da conduta do agente e do prejuízo final, denota um dano injusto, qual seja, o da chance perdida. Diante desta atual concepção do instituto da responsabilidade civil, cria-se a possibilidade do ressarcimento de danos outrora desconsiderados, tais como o da chance perdida ${ }^{31}$.

Advirta-se, contudo, que os danos provocados pelo regime militar brasileiro não se restringem ao momento histórico do período da ditadura (19641985). Tratam-se de violações a direitos humanos que tiveram consequências danosas no futuro, consistentes na perda da oportunidade da vida, de trabalho, de estudo, de constituir uma família, de deixar descendentes, ou mesmo, de apenas ter a oportunidade de usufruir livremente de sua vida, para aquilo que estivesse sujeito a acontecer. Tratam-se, portanto, de situações que se projetam para o futuro, incluindo o que estas pessoas foram, injustamente, privadas de viver dentro de uma perspectiva de vida do homem médio.

Portanto, o dano injusto, ainda que inexistente parâmetros definidos acerca de sua extensão, deve ser indenizado. A partir daí, a dúvida fica quanto à delimitação das diretrizes que devem orientar a quantificação material destes danos injustos.

A melhor solução indica que esta definição deve ser feita caso a caso, por meio da análise da vida da própria vítima e do seu entorno. Isto significa que o parâmetro a ser utilizado é o da história, das circunstâncias que circundavam suas vidas, suas perspectivas de desenvolvimento intelectual, econômico, artístico e afetivo, e as efetivas possibilidades de expansão deste contexto.

Note-se, nestes casos, que a imaterialidade dos bens e do patrimônio em jogo têm figurado como déficit para a mensuração dos danos indenizáveis. Isto é decorrência do fato de que a responsabilidade civil sempre foi muito pautada pela dimensão material dos danos. Daí a dificuldade da cultura ocidental (formada pela matriz romano-germânica) em conceituar e aceitar o dano moral e os demais danos extrapatrimoniais.

Em contrapartida, a jurisprudência internacional já vem construindo os cânones e pressupostos da responsabilização extrapatrimonial há mais tempo. A teoria da perda da chance, enquanto definidora de chances de vida perdidas, constitui-se como mais uma modalidade de danos extrapatrimoniais indenizáveis.

A doutrina parece estar se ocupando dos critérios de fixação do montante indenizatório:

\footnotetext{
${ }^{31}$ ROCHA. Vivian de Almeida Sieben. A responsabilidade civil pela perda da chance no direito brasileiro. In: Direito e Justiça, Porto Alegre, vol. 36, n. 1, p. 50, jan./jun. 2010.
} 
Para a valoração da chance perdida, deve-se partir da premissa inicial de que a chance no momento de sua perda tem um certo valor que, mesmo sendo de difícil determinação, é incontestável. É, portanto, o valor econômico desta chance que dever ser indenizado, independentemente do resultado final que a vítima poderia ter conseguido se o evento não a tivesse privado daquela possibilidade ${ }^{32}$.

Em tais casos, diante da impossibilidade de retornar ao status quo ante, e assim, de recompor o bem jurídico violado, a única forma de compensação possível é a da reparação pecuniária. Neste caso, o valor a ser concedido à vítima possuirá caráter meramente satisfativo ou compensatório dos prejuízos suportados e deve ser baseado na própria chance, levando-se em consideração o provável resultado que sobreviria, caso a chance tivesse se materializado ${ }^{33}$.

Assim, a teoria da perda de uma chance, concebida sob a perspectiva da reparação integral dos danos, é uma matriz teórica inovadora, que apresenta mais condições de amparar a responsabilização do Estado brasileiro pelos danos causados durante o regime militar, tanto materialmente quanto moralmente. $\mathrm{E}$ isso porque esta teoria é tanto considerada uma subespécie de dano emergente (que é quantificação daquilo que efetivamente se perdeu), como também pode ser utilizada como um agregador do dano moral.

Destacando a evolução da responsabilidade civil em razão das chances perdidas, Savi enfatiza que:

Durante muito tempo, o dano decorrente da perda dessa oportunidade de obter uma vantagem ou de evitar um prejuízo foi ignorado pelo Direito. Como não era possível afirmar, com certeza, que, sem o ato do ofensor, a vantagem seria obtida, ignorava-se a existência de um dano diverso da perda da vantagem esperada, qual seja, o dano da perda da oportunidade de obter aquela vantagem ${ }^{34}$.

Portanto, a partir destas conceituações, pode-se considerar a perda da chance como uma teoria apta a oferecer às vítimas e às famílias das vítimas, uma reparação mais condizente com a amplitude dos danos causados, que ainda ecoam na vida daqueles que, direta ou indiretamente, sofreram com as agressões perpetradas neste período.

Não se pode admitir que impunidade seja justificada sob o argumento

\footnotetext{
${ }^{32}$ SAVI, Sérgio. Responsabilidade civil por Perda de uma chance. São Paulo: Atlas, 2006. p. 63.

${ }^{33}$ GONDIM, Glenda Gonçalves. Responsabilidade civil: teoria da perda de uma chance. In: Revista dos Tribunais, São Paulo, vol. 840, pp. 31-33, out. 2005.

${ }^{34}$ SAVI, Sérgio. Responsabilidade civil por Perda de uma chance. São Paulo: Atlas, 2006. p. 2.
} 
de questões de confidencialidade de informações, de segurança nacional, ou de transição pacífica para a democracia. As vítimas dos atos atentatórios aos direitos humanos cometidos durante o regime militar não podem ter seus direitos mitigados com base em tais alegações, que não passam de meras justificativas para obstar a averiguação da verdade dos fatos ocorridos.

Observe-se, por outro lado, a inexistência de espaço para a responsabilização pelas chances perdidas no campo da responsabilidade civil objetiva do Estado, razão pela qual se faz necessária sua revisão para que se ajuste aos novos parâmetros indenizatórios que vêm sendo aplicados na esfera internacional.

Saliente-se, por oportuno, que a responsabilização se faz necessária, não apenas para que as vítimas e seus familiares recebam a reparação pelos danos sofridos, mas, principalmente, para assinalar o comprometimento do Estado com o esclarecimento da verdade, o respeito à memória e a busca pela justiça.

Consoante exposto em seu preâmbulo, a Constituição de 1988 institui um "Estado democrático destinado a assegurar o exercício dos direitos sociais e individuais, a liberdade, a segurança, o bem-estar, o desenvolvimento, a igualdade e a justiça como valores supremos de uma sociedade"; que tem como fundamentos (art. $1^{\circ}, \mathrm{CF} / 88$ ) a cidadania (inciso II) e a dignidade da pessoa humana (III), e que elegeu como um de seus objetivos (art. $3^{\circ}$ ), a construção de uma sociedade livre, justa e solidária (inciso I).

Um Estado constituído sob tais fundamentos não pode mais compactuar com uma visão ultrapassada, que não responsabiliza, de forma satisfatória, os responsáveis pelas notórias violações de direitos humanos, em prol de um positivismo jurídico exacerbado e violador do direito à verdade, à memória e à justiça.

\section{Conclusão}

O regime militar brasileiro foi marcado por graves violações dos direitos humanos, que marcaram um período infausto e pouco discutido da história brasileira. Estas atrocidades foram cometidas sob a guarida do Estado, que realizava suas ações em prol da "segurança e defesa" nacional. Adicione-se a este contexto, a Lei $\mathrm{n}^{\circ} 6.683 / 79$, que, por meio de um recorte espaço-temporal, anistiou os agressores que cometeram crimes naquele período.

Conquanto se tenha procedido a algumas tentativas de reparação, como os percentuais indenizatórios fixados pela Lei $n^{\circ} 9.140 / 95$, o fato é que o tema ainda não recebeu a tutela adequada. Como demonstrado, os danos sofridos pelas vítimas do regime militar possuem prospecções futuras verossímeis, enquadrando-se nos requisitos exigidos para a indenização pelas chances perdidas. E isto porque há fortes indícios de que, caso o Estado brasileiro 
não tivesse procedido, por meio de seus agentes, a estas condutas de tortura, morte e desaparecimento, as vidas das vítimas da repressão teriam um desfecho diferente.

Por outro lado, a teoria da responsabilidade civil objetiva do Estado, por si só, não se afigura capaz de compensar danos causados pelo regime militar em sua integralidade, em especial, porque exige certeza a respeito do nexo causal, que no caso das chances perdidas, não é absoluto, tendo em vista que não se pode garantir, de forma incontestável, que, ausente a conduta danosa, os prejuízos não teriam ocorrido.

De qualquer forma, o fato é que, ocorrendo um dano injusto, surge o dever ressarcitório. E, no caso das chances perdidas, não se pode olvidar que, a oportunidade perdida possui um valor que, ainda que de difícil mensuração, é incontroverso.

Portanto, estas pretensões reparatórias podem obter seu fundamento a partir da teoria da perda da chance, que, dentro da ótica da reparação integral dos danos, pode oferecer soluções mais condizentes às variadas dimensões de direitos afetadas pelas agressões perpetradas durante o regime militar. 


\section{REFERÊNCIAS}

BRASIL. Direito à verdade e à memória: Comissão Especial sobre Mortos e Desaparecidos Políticos. Brasília: Secretaria Especial dos Direitos Humanos, 2007.

. Superior Tribunal de Justiça. AgRg noAg. 1.391.062/RS. Relator Benedito Gonçalves, Primeira Turma, julgado em 09/08/2012, DJ 16/08/2012. Disponível em http://www.stj.jus.br. Acessado em 23.08. 2012.

. Superior Tribunal de Justiça. AgRg no REsp 1251529/PR. Relator Benedito Gonçalves, Primeira Turma, julgado em 28/06/2011, DJ 01/07/2011. Disponível em http://www.stj.jus.br. Acessado em 23.08.2012.

. Superior Tribunal de Justiça. EREsp 816209/RJ. Relatora Ministra Eliana Calmon, Primeira Seção, julgado em 28/10/2009, DJ 10/11/2009. Disponível em http://www.stj.jus.br. Acessado em 23.08.2012.

. Superior Tribunal de Justiça. REsp 788459/BA. Relator Fernando Gonçalves, Quarta Turma, julgado em 08/11/2005, DJ 13/03/2006. Disponível em http://www.stj.jus.br. Acessado em 23.08.2012.

. Superior Tribunal de Justiça. REsp 788459/BA. Relator Fernando Gonçalves, Quarta Turma, julgado em 08/11/2005, DJ 13/03/2006. Disponível em http://www.stj.jus.br. Acessado em 23.08.2012.

. Supremo Tribunal Federal. ADPF 153, Rel. Ministro Eros Grau. Tribunal Pleno, julgado em 29/04/2010, DJ 06/08/10. Disponível em: http:// www.stj.jus.br. Acessado em 23.08.2012.

CORTE INTERAMERICANA DE DIREITOS HUMANOS. Demanda da Comissão Interamericana de Direitos Humanos perante a Corte Interamericana de Direitos Humanos contra a República Federativa do Brasil: Caso 11.552 - Julia Gomes Lund e Outros (Guerrilha do Araguaia). In: Revista Anistia Política e Justiça de Transição, Brasília: Ministério da Justiça, n. 2, pp. 373-480, jul./dez. 2009.

DINIZ, Maria Helena. Curso de direito civil brasileiro, 7. vol. São Paulo: Saraiva, 2007.

GONDIM, Glenda Gonçalves. Responsabilidade civil: teoria da perda de uma chance. Revista dos Tribunais, São Paulo, vol. 840, pp. 11-36, out. 2005. 
LEWANDOWSKI, Enrique Ricardo. O Tribunal Penal Internacional: de uma cultura de impunidade para uma cultura de responsabilidade. In: Estudos Avançados, São Paulo, vol. 16, n. 45, pp. 187-197 maio/ago 2002.

MEIRELLES, Hely Lopes. Direito administrativo brasileiro. 25. ed. São Paulo: Malheiros Editores, 2000.

QUEIROZ, Carlos Alberto Marchi de. Crime político e crime comum. Disponível em: www.adesp.org.br. Acessado em 05.05.2012.

OLIVEIRA, Almir de. Curso de Direitos Humanos. Rio de Janeiro: Forense, 2000, pp. 97-98.

ROCHA. Vivian de Almeida Sieben. A responsabilidade civil pela perda da chance no direito brasileiro. In: Direito e Justiça, Porto Alegre, vol. 36, n. 1, pp. 45-60, jan./jun. 2010.

RODYCZ, Wilson Carlos. A responsabilidade civil das empresas privadas por danos causados na prestação de serviços públicos delegados. In: Revista de Direito do Consumidor, São Paulo, n. 45, pp. 192-227, jan./março 2003.

SAVI, Sérgio. Responsabilidade civil por Perda de uma chance. São Paulo: Atlas, 2006.

WEUCHERT, Marlon; FÁVERO, Eugênia Augusta Gonzaga. Crimes cometidos no Brasil durante o regime militar por agentes públicos contra a população civil: dever estatal de apurar e responsabilizar. Texto apresentado no $8^{\circ}$ Encontro Nacional da $2^{\mathrm{a}}$ Câmara Criminal do Ministério Público Federal. Disponível em: http://www.2ccr.pgr.mpf.gov.br. Acessado em 23.08.2012. 